\title{
Lokuskipti vegna ósæðarlokuprengsla á Íslandi 2002-2006: Ábendingar og snemmkomnir fylgikvillar
}

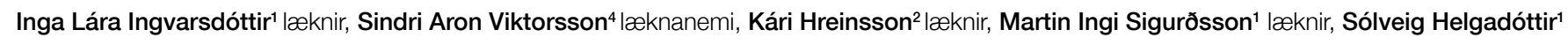
læknir, Pórarinn Arnórsson ${ }^{1}$ æknir, Ragnar Danielsen ${ }^{3,4}$ læknir, Tómas Guðbjartsson ${ }^{1,4}$ ææknir

\section{ÁGRIP}

Inngangur: Ósæðarlokuskipti eru önnur algengasta hjartaaðgerðin á íslandi og er oftast gerð vegna ósæðarlokuprengsla. Tilgangurinn var að kanna ábendingar, snemmkomna fylgikvilla og skurðdauða eftir pessar aðgerðir hér á landi.

Efniviður og aðferðir: Afturskyggn rannsókn á sjúklingum sem gengust undir ósæðarlokuskipti vegna ósæðarlokuprengsla á Landspítala 2002-2006, samtals 156 einstaklingum. Skráðir voru fylgikvillar aðgerðanna og ein- og fjölpáttagreiningu beitt til að skilgreina áhættupætti fylgikvilla og skurðdauða innan 30 daga.

Niðurstöður: Meðalaldur var 71,7 ár (bil 41-88) og voru karlar 64,7\% hópsins. Algengustu einkenni sjúklinga fyrir aðgerð voru mæði (86,9\%) og hjartaöng (52,6\%). Međalútfallsbrot hjarta (EF) var 57,2\%, hámarksprýstingsfall $(\Delta \mathrm{P})$ yfir lokuna $74,1 \mathrm{mmHg}$ og EuroSCORE (st) 6,9\%. Ríflega helmingur sjúklinganna gekkst samtímis undir kransæðahjáveitu og 9 undir aðgerð á míturloku. Lífrænni loku var komið fyrir i 127 aðgerðanna (81,4\%), í 102 tilvikum grindarlausri loku, og gerviloku hjá 29 sjúklingum. Meðalstærð ígræddra loka var 25,6 mm (bil 21-29) og að̆gerðartími var 282 mínútur. Algengustu fylgikvillar eftir aðgerð voru nýtilkomið gáttatif (78,0\%) og bráður nýrnaskaði (36,0\%). Enduraðgerð vegna blæðingar purfti i 17,0\% tilfella og 20 sjúklingar (13,0\%) fengu fjöllíffærabilun. Miđgildi legutíma var 13 dagar og 6,4\% sjúklinga létust innan 30 daga frá ađgerð.

Ályktun: Fylgikvillar reyndust tíðir eftir pessar aðgerðir, einkum gáttatif, nýrnaskaði og blæðingar sem krefjast enduraðgerðar. Skurðdauði er helmingi tíðari en eftir kransæðahjáveituaðgerðir, sem er í samræmi við erlendar rannsóknir.

${ }^{1}$ Hjarta- og lungnaskurðdeild, 2svæfinga- og gjörgæsludeild, ${ }^{3}$ hjartadeild, Landspítala, ${ }^{4}$ ææknadeild $\mathrm{HI}$.

Fyrirspurnir: Tómas Guðbjartsson tomasgud@landspitali.is

Barst: 23. apríl 2011, sampykkt til birtingar: 7. júlí 2011.

\section{Inngangur}

Ósæðarlokuprengsli (aortic stenosis) er algengt vandamál á Íslandi líkt og annars staðar á Vesturlöndum. ${ }^{1}$ Einkenni eru væg í byrjun en með vaxandi prengslum kemur fram mæði vegna hjartabilunar, brjóstverkur og yfirlið við áreynslu. Skyndidauði er einnig vel pekktur fylgikvilli. ${ }^{1}$ Tíðni ósæðarlokuprengsla eykst með hækkandi aldri og um 2\% einstaklinga um sjötugt hafa sjúkdóminn og $4 \%$ peirra sem eru komnir yfir 85 ára aldur. ${ }^{2}$ Orsakir ósæðarlokuprengsla eru meðal annars aldurstengdar breytingar í lokublöðunum og aukið álag á pau eins og sést við tvíblaða ósæðarloku. Petta veldur íferð bólgufrumna, lípíða, próteina og kalks í lokublöðin. ${ }^{3}$ prengslin gera pað að verkum að tæming vinstri slegils verður tregari, hjartavöðvinn pykknar og hann verður síður eftirgefanlegur.

Hefðbundin meðferð við óæðarlokuprengslum er skurðaðgerð par sem lokunni er skipt út en á undanförnum árum hefur einnig próast aðferð par sem nýrri ósæðarloku er komið fyrir með hjartapræðingartækni, oftast í gegnum náraslagæð. ${ }^{4}$ Hér á landi eru ósæðarlokuprengsli ábending um pað bil 75\% ósæðarlokuskipta, ${ }^{5}$ en meðal annarra ábendinga eru lokuleki eftir hjartapelsbólgu eða vegna víkkunar á ósæðarrót. ${ }^{6}$ Helsta ábending ósæðarlokuskipta vegna ósæðarlokuprengsla er sjúkdómur sem veldur einkennum samfara auknu meðalprýstingsfalli $(>40 \mathrm{mmHg}$ ) og flæðishraða (>4 m/s) yfir ósæðarlokuna, eða skertu flatarmáli lokunnar $\left(<1,0 \mathrm{~cm}^{2}\right)$. Hjá einkennalausum sjúklingum getur aðgerð einnig komið til greina samhliða annarri hjartaaðgerð eða við mikla prengingu á lokunni. ${ }^{6}$

pegar skipt er um ósæðarloku með skurðaðgerð er notast við hjarta- og lungnavél. Lokunni er síðan skipt út fyrir lífræna loku eða gerviloku úr hertu kolefni. Lífrænu lokurnar eru oftast úr svíni eða gollurshúsi kálfs. Pær geta verið með grind eða grindarlausar (stentless) og er grindin oftast gerð úr plastefni eða málmi. Sjúklingar sem fá gerviloku purfa ævilanga blóðpynningarmeðferð með warfaríni með tilheyrandi blæðingarhættu. ${ }^{7}$ Gervilokur hrörna ekki með tímanum eins og pær lífrænu en kostur við síðarnefndu lokurnar er að sjúklingarnir sleppa við langtímablóðpynningu. ${ }^{8}$ Hægt er að skipta lífrænum lokum út að nýju en slík aðgerð er tæknilega flóknari og skurðdauði helmingi tíðari en við fyrstu lokuskipti. ${ }^{9}$ Lífrænar lokur henta pví síður ungu fólki og er gjarnan miðað við 65 ára aldur eða að sjúklingur sé talinn eiga 15-20 ár eftir ólifuð. ${ }^{8}$

Ósæðarlokuskipti hafa verið framkvæmd frá 1987 á Íslandi og eru næstalgengasta opna hjartaaðgerðin hér á landi. ${ }^{5}$ Upplýsingar um árangur aðgerðanna á Íslandi hafa ekki legið fyrir. Markmið pessarar rannsóknar var að kanna árangur peirra á Landspítala á fimm ára tímabili, með áherslu á snemmkomna fylgikvilla og dánartíðni innan 30 daga frá aðgerð.

\section{Efniviður og aðferðir}

Rannsóknin var afturskyggn og náði til sjúklinga sem gengust undir ósæðarlokuskipti á Landspítala frá 1 . janúar 2002 til 31. desember 2006. Listi yfir sjúklinga var fenginn úr tveimur aðskildum skrám, annars vegar úr sjúklingabókhaldi Landspítala par sem leitað var að aðgerðanúmerum fyrir ósæðarlokuskiptaaðgerð 
Tafla I. Lokutegundir sem græddar voru í 156 sjúklinga sem gengust undir aðgerð vegna ósæðarlokuprengsla á Landspítala 2002-2006. Gefinn er upp fjöldi sjúklinga og \% ísviga.

\begin{tabular}{|c|c|}
\hline \multicolumn{2}{|l|}{ Gervilokur $(n=29)$} \\
\hline CarboMedics $^{\circledast}$ & $20(12,8)$ \\
\hline St. Jude Medical ${ }^{\circledR}$ & $6(3,8)$ \\
\hline St. Jude Medical Regent ${ }^{\circledR}$ & $3(1,9)$ \\
\hline \multicolumn{2}{|l|}{ Lífrænar lokur, grindarlausar $(n=102)$} \\
\hline Medtronic Freestyle ${ }^{\circledR}$ & $100(64,1)$ \\
\hline St. Jude Toronto ${ }^{\circledR}$ & $2(1,3)$ \\
\hline \multicolumn{2}{|l|}{ Lífrænar lokur með grind $(n=25)$} \\
\hline Carpentier-Edwards Perimount ${ }^{\circledR}$ & $17(10,9)$ \\
\hline Carpentier-Edwards Perimount Magna ${ }^{\circledast}$ & $8(5,1)$ \\
\hline Samtals & $156(100)$ \\
\hline
\end{tabular}

(FMD00 eða FMD10) og hins vegar úr gagnagrunni hjarta- og lungnaskurðdeildar Landspítala.

Á pessum fimm árum gengust 185 manns undir ósæðarlokuskipti á Landspítala. Útilokaðir voru 17 sjúklingar sem áður höfðu farið í hjartaaðgerð, tveir með hjartapelsbólgu og prír sem gengust undir ósæðarlokuskipti vegna ósæðarlokuleka. Einnig var sjö sjúklingum sleppt par sem sjúkraskrár peirra fundust ekki. Í rannsóknarbýði voru pví 156 sjúklingar sem gengust undir ósæðarlokuskipti vegna ósæðarlokuprengsla.

Klínískar upplýsingar fengust úr sjúkraskrám og voru skráðar samtals 113 breytur, par á meðal aldur, kyn og áhættupættir hjarta- og æðasjúkdóma. Einkenni sjúklinga voru metin samkvæmt flokkun NYHA (New York Heart Association) á hjartabilun. Einnig var reiknað út EuroSCORE (bæði standard og lógistískt) fyrir alla sjúklinga, en pað er áhættulíkan sem metur dánarlíkur við hjartaaðgerð. Par að auki voru skráðar niðurstöður úr hjartaómskoðunum sem gerðar voru fyrir aðgerð og um pað bil viku eftir aðgerð. Úr ómsvörum var skráð hámarksprýstingsfall yfir ósæðarlokuna, hvort lokuleki var til staðar og útfallsbrot vinstri slegils (ejection fraction, EF), ásamt veggpykkt og stærð hans í pan- og slagbili. Flatarmál lokuprengsla var metið með samfellulíkingu (continuity equation) út frá hjartaómun. Skráð var ábending fyrir aðgerð og lyf við innskrift, par á meðal hjartalyf, blóðfitulækkandi lyf og lyf sem hemja blóðflögur. Einnig var kannað hvort sjúklingarnir voru á blóðpynningu með warfaríni eða léttheparíni. Skráð var hvort kransæðasjúkdómur var til staðar og pá hversu alvarlegur og útbreiddur hann var. Jafnframt var skráð hvort um val- eða bráðaaðgerð væri að ræða, hvaða tegund loku var komið fyrir og hvort önnur aðgerð hafi verið framkvæmd samtímis lokuskiptunum. Einnig var skráður tími á hjarta- og

Tafla II. Niðurstöður hjartaómana fyrir aðgerð hjá sjúklingum sem gengust undir lokuskipti vegna ósæðarlokuprengsla á Íslandi 2002-2006. Gefin eru upp meðaltöl með staðalfráviki.

\begin{tabular}{lc}
\hline Útfallsbrot $(\%)$ & $57,2 \pm 7,7$ \\
\hline Flatarmál lokuops $\left(\mathrm{cm}^{2}\right)$ & $0,63 \pm 0,23$ \\
\hline Vídd vinstri slegils í panbili $(\mathrm{cm})$ & $5,3 \pm 0,9$ \\
\hline Pykkt sleglaskiptar $(\mathrm{cm})$ & $1,41 \pm 0,31$ \\
\hline Pykkt á bakvegg vinstra slegils $(\mathrm{cm})$ & $1,25 \pm 0,24$ \\
\hline Hámarksprýstingsfall $(\mathrm{mmHg})$ & $74,1 \pm 25,3$ \\
\hline
\end{tabular}

lungnavél, tangar- (aortic cross clamp time) og aðgerðatími.

Fylgikvillar eftir aðgerð voru skráðir ítarlega og var áhersla lögð á snemmkomna fylgikvilla sem voru skilgreindir sem fylgikvillar sem komu innan fjögurra vikna frá aðgerð. Aðrir fylgikvillar voru flokkaðir sem langtímafylgikvillar. Til alvarlegra fylgikvilla töldust hjartadrep (skilgreint sem einangraðar ST-breytingar eða nýtilkomið vinstra greinrof á hjartalínuriti ásamt hækkun á hjartaensíminu CK-MB yfir 70 g/L), heiladrep og miðmætisbólga en einnig fjöllíffærabilun og enduraðgerð vegna blæðingar. Minniháttar fylgikvillar voru hins vegar hjartsláttartruflanir, pvagfærasýking, lungnabólga, aftöppun fleiðruvökva, afturkræf blóðpurrð í heila og grunn skurðsárasýking. Nýrnaskaði (acute renal injury) taldist einnig til minniháttar fylgikvilla og var metinn samkvæmt RIFLE-skilmerkjum. Sjúklingar sem féllu í áhættu- ( $R=$ risk), skaða- (I=injury) eða bilunarflokk ( $F=$ failure) voru skilgreindir með bráðan nýrnaskaða. Skráð var magn blæðingar á fyrstu 24 klukkustundunum eftir aðgerð. Legutími var skráður í dögum, bæði á gjörgæslu og heildarlegutími. Athugað var hversu margir sjúklingar létust innan 30 daga frá aðgerð sem er hefðbundin skilgreining á skurðdauða (operative mortality).

Upplýsingar voru skráðar í forritið Excel en tölfræðiútreikningar voru unnir í forritinu R, útgáfu 2.11.0 ( $\mathrm{R}$ foundation, Austria). Við samanburð hópa var stuðst við t-próf fyrir samfelldar breytur og Fisher Exact eða Kí-kvaðrat próf fyrir hlutfallsbreytur. Marktæki miðaðist við p-gildi <0,05. Einpáttagreining á áhættupáttum skurðdauða, alvarlegra og minniháttar fylgikvilla var gerð með t-prófi fyrir samfelldar breytur og Kí-kvaðrat eða Fisher Exact fyrir flokkabreytur. Pær breytur sem höfðu p-gildi undir 0,1 voru notaðar í fjölpátta lógistískt líkan fyrir skurðdauða, auk alvarlegra og minniháttar fylgikvilla. Grunnlíkanið var svo notað til að búa til besta líkan með pví að fella út breytur úr líkaninu par til besta líkanið var fundið. Petta var gert handvirkt en einnig á sjálfvirkan hátt með „stepwise backwards“ aðferð.

Áður en rannsóknin hófst fengust öll tilskilin leyfi frá Vísindasiðanefnd, Persónuvernd og framkvæmdastjóra lækninga á Landspítala.

\section{Niðurstöður}

Af 156 sjúklingum voru 101 karlar (64,7\%) og 55 konur (35,3\%). Meðalaldur sjúklinga var 71,7 \pm 9,2 ár og var sá yngsti 41 árs og elsti sjúklingurinn 88 ára.

Að meðaltali var framkvæmd 31 aðgerð á ári (bil 18-39). Lífrænni loku var komið fyrir í 127 sjúklingum (81,4\%) og fengu 102 peirra grindarlausar lokur $(65,4 \%)$ en 25 loku með grind $(16,0 \%)$. Meðalaldur peirra sem fengu lífræna loku var $74,8 \pm 5,8$ ár (bil 48-88) og peirra sem fengu gerviloku 58,5 \pm 9,7 ár (bil 41-85) ( $\mathrm{p}<0,001)$, en kynjaskipting reyndist svipuð. Allar grindarlausu lokurnar voru af Medtronic Freestyle ${ }^{\circledast}$ gerð nema tvær, en Carpentier-Edwards Perimount ${ }^{\circledR}$ var algengasta lífræna lokan með grind ( $n=17)$. Gervilokum var komið fyrir í 29 sjúklingum $(18,6 \%)$ og voru $20(69,0 \%)$ peirra af CarboMedics ${ }^{\circledR}$ gerð. Í töflu I er listi yfir lokur sem græddar voru í sjúklingana 156.

Af helstu áhættupáttum hjartasjúkdóma höfðu flestir sjúklinganna sögu um reykingar (70,5\%) og álíka margir höfðu háprýsting (69,2\%). Nokkru færri höfðu blóðfituhækkun (43,6\%) og sykursýki 
Tafla III. Yfirlit yfir sjúklinga sem létust innan 30 daga eftir lokuskiptaaðgerð vegna ósæðarlokuprengsla á Landspítala $2002-2006$.

\begin{tabular}{|c|c|c|c|c|c|c|c|c|c|c|c|c|c|}
\hline Nr. & $\begin{array}{l}\text { Aldur/ } \\
\text { Kyn }\end{array}$ & $\begin{array}{l}\text { NYHA } \\
\text { flokkur }\end{array}$ & $\begin{array}{c}\text { Euro- } \\
\text { SCORE } \\
(\log )\end{array}$ & $\begin{array}{l}\text { Prýstings } \\
\text { fall/loku- } \\
\text { flatarmál } \\
\text { fyrir aðgerð }\end{array}$ & $\begin{array}{l}\text { Út- } \\
\text { falls- } \\
\text { brot } \\
(\%)\end{array}$ & $\begin{array}{c}\text { Lífræn } \\
\text { loka } \\
\text { með } \\
\text { grind }\end{array}$ & $\begin{array}{l}\text { Stærð } \\
\text { loku } \\
(\mathrm{mm})\end{array}$ & $\begin{array}{c}\text { Tangar- } \\
\text { tími } \\
\text { (mín) }\end{array}$ & $\begin{array}{l}\text { Lifun } \\
\text { (dagar) }\end{array}$ & $\begin{array}{l}\text { Blóðgjöf } \\
\text { (ein) }\end{array}$ & $\begin{array}{c}\text { Fjöl- } \\
\text { kerfa- } \\
\text { bilun }\end{array}$ & $\begin{array}{l}\text { Endur- } \\
\text { aðgerð }\end{array}$ & Athugasemd \\
\hline 1 & $82 / \mathrm{Kvk}$ & III & 22,9 & $70 / 0,6$ & 35 & + & 21 & 110 & 16 & 19 & + & + & Mikil brenglun í blóðstorku \\
\hline 2 & $77 /$ Kk & IV & 4,8 & $70 / 0,6$ & 60 & - & 25 & 132 & 6 & 11 & - & + & Rof á hægri slegli í enduraðgerð \\
\hline 3 & $83 / \mathrm{Kvk}$ & IV & 40,9 & $92 / 0,4$ & 53 & + & 23 & 98 & 9 & 12 & + & - & Einnig míturlokuaðgerð \\
\hline 4 & $83 / \mathrm{Kk}$ & IV & 7,5 & $156 / 0,2$ & 55 & + & 27 & 114 & 13 & 9 & + & - & \\
\hline 5 & $64 / \mathrm{kvk}$ & III & 25,2 & $39 / 0,8$ & 40 & + & 21 & 177 & 17 & 19 & - & + & Einnig míturlokuaðgerð \\
\hline 6 & $81 / \mathrm{Kk}$ & III & 74,7 & $81 / 0,74$ & 45 & - & 23 & 163 & 21 & 13 & + & + & \\
\hline 7 & 70/Kvk & III & 4,2 & $65 / 0,6$ & 55 & + & 21 & 146 & 2 & 18 & + & - & $\begin{array}{l}\text { Mikil blæðing og brenglun } \\
\text { í blóðstorku }\end{array}$ \\
\hline 8 & 78/Kvk & 1 & 10,3 & $100 / 0,5$ & 43 & - & 23 & 244 & 0 & 0 & - & - & Lést í aðgerð \\
\hline 9 & $75 / \mathrm{Kk}$ & III & 4,3 & $60 / 0,7$ & 60 & - & 25 & 111 & 2 & 4 & - & - & $\begin{array}{l}\text { Blæðandi magasár og } \\
\text { ásvelgingslungnabólga }\end{array}$ \\
\hline 10 & $80 /$ Kvk & III & 12,4 & $88 / 0,7$ & 60 & - & 25 & 98 & 12 & 27 & + & + & \\
\hline
\end{tabular}

${ }^{*} \mathrm{mmHg} / \mathrm{cm}^{2}, \mathrm{Kvk}=$ kvenkyn, $\mathrm{Kk}=$ karlkyn.

(17,3\%). Líkamspyngdarstuðull (BMI, Body Mass Index) var að meðaltali $27,4 \pm 4,4$ og EuroSCORE (st) var að meðaltali $6,9 \pm$ 3,0 (bil 2-18).

Mæði var algengasta einkennið, eða hjá 126 sjúklingum (86,9\%). Hjartaöng höfðu 82 sjúklingar (56,6\%), par af voru 25 með óstöðuga hjartaöng. Alls voru 63 sjúklingar (43,5\%) með bæði mæði og hjartaöng. Hjartabilun greindist hjá 55 sjúklingum $(37,9 \%)$ og 17 sjúklingar (11,7\%) höfðu fengið hjartadrep í aðdraganda innlagnar. Sjúklingar með sögu um yfirlið voru 21 (14,5\%) en peir höfðu allir að auki sögu um hjartabilun og 19 peirra $(13,1 \%)$ hjartaöng. Ellefu sjúklingar $(7,1 \%)$ voru án einkenna og greindust við heilsueftirlit eða fyrir tilviljun.

Sjúklingar á NYHA-stigum III-IV voru 89 (57,1\%) en 15 (9,6\%) voru í flokki I. Af sjúklingum sem fengu lífræna loku með grind voru 20 (80\%) á NYHA-stigum III-IV borið saman við 54 (52,9\%) peirra sem fengu grindarlausa loku $(\mathrm{p}=0,01)$.

Niðurstöður hjartaómskoðana fyrir aðgerð eru sýndar í töflu II. Útfallsbrot vinstri slegils var að meðaltali 57,2\% fyrir aðgerðina og meðal lokuflatarmál $0,63 \mathrm{~cm}^{2}$. Vídd vinstri slegils í panbili (left ventricular end diastolic diameter), mældist $5,3 \mathrm{~cm}$ að meðaltali fyrir aðgerðina en $5,2 \mathrm{~cm}$ viku eftir hana $(\mathrm{p}=0,16)$. Hámarksprýstingsfall yfir ósæðarlokuna var að meðaltali $74,1 \mathrm{mmHg}$ fyrir aðgerð en mældist $28,1 \mathrm{mmHg}$ viku eftir aðgerð $(\mathrm{p}<0,0001)$.

Meðal tangartími var $124 \pm 41$ mínútur (bil 57-280), vélartími $167 \pm 55,5$ mínútur (bil 74-452) og aðgerðartími $282 \pm 88$ mínútur (bil 135-690). Marktækur munur var á tangartíma sjúklinga sem fengu lífræna loku með grind og peirra sem fengu grindarlausa loku og munaði 25 mínútum (108 borið saman við 133 mínútur, $\mathrm{p}=0,005)$. Kransæðahjáveituaðgerð var framkvæmd hjá 86 sjúklingum samhliða ósæðarlokuskiptunum (55,1\%), oftar hjá sjúklingum með lífræna grindarlausa loku $(64,7 \%)$ en með grind $(44,0 \%)(p=0,01)$. Stærð ígræddrar loku var að meðaltali 25,6 mm; 24,0 mm fyrir lokur með grind og 26,0 mm fyrir grindarlausar lokur $(\mathrm{p}<0,001)$.

Heildarlegutími var 13 dagar (miðgildi, bil 0-207), par með talinn einn dagur (miðgildi) á gjörgæslu (bil 0-80).

Tíu sjúklingar létust innan 30 daga frá aðgerð og skurðdauði pví 6,4\%. Í töflu III er yfirlit yfir pessa 10 sjúklinga. Meðalaldur peirra sem létust var 77,3 ár og flestir voru með alvarleg ósæðarlokuprengsli eða aðra undirliggjandi sjúkdóma. Pannig voru allir að einum undanskildum í NYHA-flokki III eða IV fyrir aðgerð og meðal EuroSCORE (st) 9,6 og logEuroSCORE 20,7. Flestir létust innan viku frá aðgerð, oftast vegna fjöllíffærabilunar, og einn sjúklingur lést á skurðarborðinu vegna blæðingar. Hjá tveimur sjúklingum var gerð míturlokuaðgerð samtímis. Auk sjúklinganna 10 í töflu III var einn sem lést á sjúkrahúsi 33 dögum eftir aðgerð, en í aðgerðinni hafði einnig verið framkvæmd MAZE-aðgerð og ígrædd gervimíturloka. Dánarorsök hans var fjöllíffærabilun.

Í töflu IV sjást snemmkomnir fylgikvillar eftir aðgerð. Niðurstöður miðast við fjölda sjúklinga sem fengu tiltekna fylgikvilla og aðeins pá sem lifðu aðgerðina af $(n=153)$. Ennfremur gat sami sjúklingur fengið fleiri en einn fylgikvilla. Alvarlega fylgikvilla fengu samtals 52 sjúklingar $(33,4 \%)$ og var enduraðgerð vegna blæðingar algengust $(17,0 \%)$ en næst komu blóðpurrð í hjarta $(14,4 \%)$ og fjöllíffærabilun (13,0\%). Samtals fengu 129 sjúklingar minniháttar fylgikvilla. Flestir fengu nýtilkomið gáttatif/flökt, eða 93 sjúklingar (77,5\%). Alls greindust 52 sjúklingar (35,9\%) með nýrnaskaða en pvagfærasýkingu fengu 30 (19,6\%) og lungnabólgu 22 sjúklingar (14,4\%). Aðrir fylgikvillar voru sjaldgæfari.

Í fjölpáttagreiningu reyndist stærra lokuflatarmál (OR=0,93, 95\% CI 0,87-1,00) sjálfstæður verndandi áhættupáttur fyrir skurðdauða. Gjöf rauðkornapykknis reyndist eini sjálfstæði áhættupáttur alvarålegra fylgikvilla í kjölfar aðgerðar (OR=1,3, 95\% CI 1,16-1,45, $\mathrm{p}<0,001)$. Loks reyndust hærri aldur ( $\mathrm{OR}=1,08,95 \%$ CI 1,01-1,15, $\mathrm{p}=0,034)$, háprýstingur ( $\mathrm{OR}=3,07,95 \% \mathrm{CI} 1,17-8,05, \mathrm{p}=0,023)$ og hjartabilun (OR=5,64, 95\% CI 1,10-29,03, p=0,038) sjálfstæðir áhættupættir minniháttar fylgikvilla.

\section{Umræða}

Pessi rannsókn sýnir að snemmkomnir fylgikvillar eru tíðir eftir ósæðarlokuskipti vegna ósæðarlokuprengsla. Fjórir af hverjum fimm sjúklingum greindust með minniháttar fylgikvilla, sem verður að teljast hátt hlutfall enda pótt svipuðum niðurstöðum hafi verið lýst í öðrum rannsóknum. ${ }^{10}$ Algengasti fylgikvillinn var gáttatif, hjá 77,5\% sjúklinga. Petta er hátt hlutfall í samanburði við 
Tafla IV. Tíoni fylgikvilla hjá 153 sjúklingum sem gengust undir lokuskipti vegna ósæðarlokuprengsla á Íslandi á tímabilinu 2002-2006. Sleppt er premur sjúklingum sem ekki komu lifandi úr aðgero. Sami sjúklingur getur haft fleiri en einn fylgikvilla. Gefinn er upp fjöldi sjúlinga og \% i sviga.

\begin{tabular}{lc}
\hline Alvarlegir fylgikvillar & $52(33,4)$ \\
\hline Enduraðgerð vegna blæðingar & $26(17,0)$ \\
\hline Blóðpurrð í hjarta & $22(14,4)$ \\
\hline Fjöllíffærabilun & $20(13,0)$ \\
\hline Blóðpurrð í heila & $2(1,3)$ \\
\hline Miðmætisbólga & $0(0,0)$ \\
\hline Minniháttar fylgikvillar & $129(84,3)$ \\
\hline Nýtilkomið hjartatif/flökt & $93(77,5)$ \\
\hline Nýrnaskaði & $52(35,9)$ \\
\hline Pvagfærasýking & $30(19,6)$ \\
\hline Lungnabólga & $22(14,4)$ \\
\hline Aftöppun fleiðruvökva & $21(13,7)$ \\
\hline Yfirborðssýking í skurðsári & $13(8,5)$ \\
\hline Afturkræf blóðpurrð í heila & $4(2,6)$ \\
\hline Skurðdauði (<30 daga) & $10(6,4)$ \\
\hline
\end{tabular}

erlendar rannsóknir par sem tíðnin er á bilinu 10 til 65\%. ${ }^{11,12}$ Gáttatif er algengara eftir ósæðarlokuskipti en kransæðahjáveituaðgerðir, en tíðnin eftir síðarnefndu aðgerðirnar reyndist vera 38\% í nýlegri íslenskri rannsókn. ${ }^{13}$ Ekki er ljóst af hverju tíðni gáttatifs er svo há hér á landi. Lengd eftirfylgdar í hjartarafsjá getur haft áhrif, par sem $94 \%$ nýtilkomins gáttatifs greinist innan sex daga frá aðgerð. ${ }^{14}$ Á Landspítala eru sjúklingar í hjartarafsjá í allt að viku frá aðgerð sem gæti aukið líkur á greiningu. Sennilega er pó líklegri skýring að lyfjameðferð pessara sjúklinga í kringum aðgerðina hafi verið frábrugðin. Í pessari rannsókn lágu ekki fyrir nákvæmar upplýsingar um hjartalyf sem sjúklingar tóku að morgni aðgerðardags. Pví er ekki hægt að leggja mat á hvort notkun betablokkara eða amíódaróns fyrir aðgerð sé frábrugðin pví er tíðkast annars staðar, en sums staðar erlendis eru pessi lyf gefin sérstaklega fyrir aðgerð til að lækka tíðni gáttatifs. ${ }^{12}$

Ólíkt gáttatifi var tíðni annarra minniháttar fylgikvilla, svo sem grunnra skurðsýkinga, lungnabólgu og pvagfærasýkinga sambærileg og í öðrum rannsóknum. ${ }^{15}$ Enginn tilfelli greindust af djúpum sýkingum í miðmæti en hlutfall slíkra sýkinga reyndist aðeins 2,5\% í nýlegri rannsókn á 1650 hjartaaðgerðum á Landspítala. ${ }^{16}$ Af alvarlegum fylgikvillum má helst nefna blóðpurrð í hjarta $(14,4 \%)$, og fjöllíffærabilun $(13,0 \%)$, en blóðpurrð í heila var mun sjaldgæfari (1,3\%). Svipuðum niðurstöðum hefur verið lýst erlendis. ${ }^{15}$ Pá purfti enduraðgerð vegna blæðingar hjá 17,0\% sjúklinga sem er hærra hlutfall en í erlendum rannsóknum. Petta er einnig ívið hærra hlutfall en í nýlegri rannsókn af Landspítala, en par voru rannsakaðar allar hjartaaðgerðir og var heildarhlutfall enduraðgerða 8\%. ${ }^{17}$ Hærra hlutfall í pessari rannsókn skýrist aðallega af pví að tíðni enduraðgerða vegna blæðinga er hærri eftir ósæðarlokuaðgerðir en kransæðahjáveituaðgerðir og enn hærri ef báðar aðgerðirnar eru framkvæmdar samtímis. ${ }^{17}$ Frekari rannsóknir parf til pess að útskýra háa tíðni enduraðgerða hér á landi og er slík rannsókn pegar hafin á Landspítala.

Skurðdauði reyndist 6,4\% sem er sambærilegt við aðrar rann-
Tafla V. Samanburður á helstu rannsóknum á skurðdauða ( $<30$ daga) eftir ósæðarlokuskiptaaðgerð. Tilgreindur er fyrsti höfundur, birtingarár og tegund loku.

\begin{tabular}{|c|c|c|}
\hline Rannsókn (ár) & Tegund loku & Skurðdauði (\%) \\
\hline Emery $(2005)^{21}$ & St. Jude Medical ${ }^{\circledast}$ gerviloka & 6,0 \\
\hline Khan $(2001)^{22}$ & Gervi- og lífrænar lokur & 6,1 \\
\hline Butchart $(2001)^{23}$ & Medtronic Hall ${ }^{\circledR}$ gerviloka & 4,2 \\
\hline Bach $(2005)^{24}$ & Medtronic Freestyle ${ }^{\circledR}$ & 7,1 \\
\hline Eichinger $(2008)^{25}$ & St. Jude Medical Biocor ${ }^{\text {(B) }}$ & 5,3 \\
\hline Rannsókn höfunda (2011) & Gervi- og lífrænar lokur & 6,4 \\
\hline
\end{tabular}

sóknir (tafla V), enda pótt lægri skurðdauða hafi verið lýst á stærri sjúkrahúsum erlendis. ${ }^{6}$ Skurðdauði er helmingi tíðari en eftir kransæðahjáveituaðgerðir hér á landi ${ }^{5}$ sem einnig er pekkt í öðrum rannsóknum. ${ }^{18}$

Enda pótt snemmkomnir fylgikvillar séu tíðir dvelur rúmur helmingur sjúklinga (53\%) innan við sólarhring á gjörgæslu. Heildarlegutími er hins vegar langur, eða 13 dagar, sem er lengra en í flestum sambærilegum rannsóknum par sem sjúklingar liggja oftast inni í 6-12 daga. ${ }^{19}$ Hafa ber í huga að sums staðar erlendis eru sjúklingar lagðir inn á sérhæfð sjúkrahótel eftir aðgerð og sá tími ekki talinn með í legutíma.

Í pessari rannsókn voru 81,4\% af ígræddum lokum lífrænar. Er pað í samræmi við próunina erlendis par sem notkun lífrænna loka fer vaxandi. Skýringin á pví er hærra hlutfall eldra fólks auk pess sem ending lífrænna loka fer sífellt batnandi. Hér á landi er áberandi hversu mikið er notað af lífrænum grindarlausum lokum, eða í tæplega tveimur priðju tilfella. Til samanburðar var hlutfall pessara loka í Svípjóð undir 5\% árið 2008. ${ }^{20}$ Ljóst er að árangur lokuskiptaaðgerða með grindarlausum lokum er góður hér á landi og skurðdauði aðeins 5\% við pær aðgerðir. Líkt og í öðrum rannsóknum er tangartími pó lengri og munar 25 mínútum, enda tæknilega flóknara að koma peim fyrir en lífrænum lokum með grind.

Fyrir lífrænar lokur með grind var skurðdauði fjórfalt hærri en fyrir grindarlausar lokur, eða 20\% samanborið við 5\%. Skýringin á pessum mun er ekki augljós en liggur pó sennilega í pví að sjúklingar sem fengu loku með grind voru almennt veikari. Pannig voru marktækt fleiri peirra á NYHA-stigum III og IV og pví með alvarlegri hjartasjúkdóm. Með pví að nota loku með grind hjá pessum sjúklingum var sennilega reynt að stytta tangartíma og fækka með pví fylgikvillum. EuroSCORE beggja hópa var pó sambærilegt en hafa verður í huga að EuroSCORE er ekki fullkomið spálíkan við mat á áhættu við pessar aðgerðir.

Erlendis er nú víða hætt að gera opnar lokuaðgerðir hjá sjúklingum með hátt EuroSCORE par sem miklar líkur eru á skurðdauða $(>20 \%)$. ${ }^{4}$ Hjá slíkum sjúklingum er lífrænni ósæðarloku komið fyrir með hjartapræðingartækni, oftast í gegnum náraslagæð. Einnig er hægt að koma pessum lokum fyrir í gegnum hjartabrodd og pá án pess að notast sé við hjarta- og lungnavél. Slík aðgerð krefst pó bringubeins- eða brjóstholsskurðar til að komast að hjartanu sem er ókostur í mikið veikum sjúklingum. ${ }^{4}$

Langalgengasta einkenni sjúklinga var mæði (87\%) en 7\% greindust án einkenna. Helmingur sjúklinga hafði hjartaöng og priðjungur einkenni hjartabilunar. Petta eru svipuð einkenni og 
lýst hefur verið í erlendum rannsóknum, nema hvað hjartaöng er heldur algengari. Skýringin gæti verið sú að hlutfall eldri sjúklinga með kransæðasjúkdóm er hátt, en rúmur helmingur sjúklinga gekkst undir kransæðahjáveituaðgerð samhliða lokuskiptum.

Rannsóknin er afturskyggn og óslembuð sem telst veikleiki, sérstaklega pegar kemur að pví að bera saman árangur mismunandi lokutegunda. Pessi rannsókn getur pví ekki svarað pví hvaða lífræna loka reyndist best, hvorki til skemmri né lengri tíma. Ótvíræður styrkleiki pessarar rannsóknar er hins vegar að í henni eru allir sjúklingar sem gengust undir ósæðarlokuskipti hjá heilli pjóð á fimm ára tímabili. Aðeins prír skurðlæknar framkvæmdu aðgerðirnar og nákvæmar upplýsingar lágu fyrir um afdrif allra sjúklinga nema sjö.
Í stuttu máli sagt eru snemmkomnir fylgikvillar algengir eftir ósæðarlokuskipti vegna ósæðarlokuprengsla, sérstaklega gáttatif og enduraðgerð vegna blæðinga. Skurðdauði reyndist helmingi tíðari eftir kransæðahjáveituaðgerðir sem einnig er pekkt í öðrum rannsóknum.

\section{Pakkir}

Pakkir fær Gunnhildur Jóhannsdóttir, skrifstofustjóri á skurðdeild Landspítala, en einnig Thor Aspelund tölfræðingur og Elín Maríusdóttir læknir fyrir hjálp við tölfræðilega úrvinnslu. Rannsóknin var styrkt af Vísindasjóði Landspítala og Minningarsjóði Bent Scheving Thorsteinssonar.

\section{Heimildir}

1. Freeman RV, Otto CM. Spectrum of calcific aortic valve disease: pathogenesis, disease progression, and treatment strategies. Circulation 2005; 111: 3316-26.

2. Supino PG, Borer JS, Preibisz J, Bornstein A. The epidemiology of valvular heart disease: a growing public health problem. Heart Fail Clin 2006; 2: 379-93.

3. Iung B, Vahanian A. Epidemiology of valvular heart disease in the adult. Nat Rev Cardiol 2011; 8: 162-72.

4. Dworakowski R, MacCarthy P, Monaghan M, et al. Transcatheter aortic valve implantation for severe aortic stenosis-a new paradigm. Am Heart J 2010; 160: 237-43.

5. Arnórsson P, Torfason B, Ólafsson G, Alfreðsson H, Jóhannsson KB, Guðbjartsson T. Hjartaskurðlækningar á Íslandi í 20 ár. Ágrip erinda af vísindapingi Skurðlæknafélags Íslands og Svæfinga- og gjörgæslulæknafélags Íslands. E 24. Læknablaðið 2007; 93: 320.

6. Bonow RO, Carabello BA, Chatterjee $\mathrm{K}$, et al. 2008 focused update incorporated into the ACC/AHA 2006 guidelines for the management of patients with valvular heart disease: a report of the American College of Cardiology/American Heart Association Task Force on Practice Guidelines (Writing Committee to revise the 1998 guidelines for the management of patients with valvular heart disease). Endorsed by the Society of Cardiovascular Anesthesiologists, Society for Cardiovascular Angiography and Interventions, and Society of Thoracic Surgeons. J Am Coll Cardiol 2008; 52: e1-142.

7. Horstkotte D, Schulte H, Bircks W, Strauer B. Unexpected findings concerning thromboembolic complications and anticoagulation after complete 10 year follow up of patients with St. Jude Medical prostheses. J Heart Valve Dis 1993; 2: 291-301.

8. Pibarot P, Dumesnil JG. Prosthetic heart valves: selection of the optimal prosthesis and long-term management. Circulation 2009; 119: 1034-48.
9. Maganti K, Rigolin VH, Sarano ME, Bonow RO. Valvular heart disease: diagnosis and management. Mayo Clin Proc 2010; 85: 483-500.

10. Doty JR, Flores JH, Millar RC, Doty DB. Aortic valve replacement with medtronic freestyle bioprosthesis: operative technique and results. J Card Surg 1998; 13: 208-

11. Filardo G, Hamilton C, Hamman B, Hebeler RJ, Adams J, Grayburn P. New-onset postoperative atrial fibrillation and long-term survival after aortic valve replacement surgery. Ann Thorac Surg 2010; 90: 474-9.

12. Mitchell L, Exner D, Wyse D, et al. Prophylactic Oral Amiodarone for the Prevention of Arrhythmias that Begin Early After Revascularization, Valve Replacement, or Repair: PAPABEAR: a randomized controlled trial. 2005; 294: 3093-100.

13. Helgadottir S, Sigurjónsson H, Ingvadottir IL, et al. Gáttatif eftir opnar hjartaaðgerðir á Íslandi. Í: 12. vísindaping Skurðlæknafélags Íslands og Svæfingaog giörgæslulæknafélags Íslands, 2010. E 27. www. laeknabladid.is/fylgirit/fylgirit/2010/fylgirit62 / september 2011

14. Aranki S, Shaw D, Adams D, et al. Predictors of atrial fibrillation after coronary artery surgery. Current trends and impact on hospital resources. Circulation 1996; 94: 390-7.

15. Carnero-Alcazar M, Reguillo-Lacruz F, Alswies A, Villagran-Medinilla E, Maroto-Castellanos LC, RodriguezHernandez J. Short- and mid-term results for aortic valve replacement in octogenarians. Interact Cardiovasc Thorac Surg 2010; 10: 549-54.

16. Steingrímsson S, Gottfreðsson $M$, Kristinsson $K G$, Guðbjartsson T. Deep sternal wound infections following open heart surgery in Iceland: a population-based study. Scan Cardiovasc J 2008; 42: 208-13.
17. Smárason NV, Sigurjónsson $H$, Hreinsson $K$, Arnórsson T, Guðbjartsson T. Enduraðgerðir vegna blæðinga eftir opnar hjartaskurðaðgerðir. Læknablaðið 2009; 95: 567-73.

18. Gardner S, Grunwald G, Rumsfeld J, et al. Comparison of short-term mortality risk factors for valve replacement versus coronary artery bypass graft surgery. Ann Thorac Surg 2004; 77: 549-56.

19. Weerasinghe A, Yusuf M, Athanasiou T, Wood A, Magee P, Uppal R. Role of transvalvular gradient in outcome from valve replacement for aortic stenosis. Ann Thorac Surg 2004; 77: 1266-71.

20. Årsrapport Swedeheart 2008: Riks-hia, Sephia, Scaar \& Hjärtkirurgiregistret; 2008

21. Emery RW, Krogh CC, Arom KV, et al. The St. Jude Medical cardiac valve prosthesis: a 25 -year experience with single valve replacement. Ann Thorac Surg 2005; 79: 776-82; discussion 82-3.

22. Khan SS, Trento A, DeRobertis M, et al. Twenty-year comparison of tissue and mechanical valve replacement. J Thorac Cardiovasc Surg 2001; 122: 257-69.

23. Butchart EG, Li HH, Payne N, Buchan K, Grunkemeier GL. Twenty years' experience with the Medtronic Hall valve. J Thorac Cardiovasc Surg 2001; 121: 1090-100.

24. Bach DS, Kon ND, Dumesnil JG, Sintek CF, Doty DB. Ten-year outcome after aortic valve replacement with the freestyle stentless bioprosthesis. Ann Thorac Surg 2005; 80: 480-6; discussion 6-7.

25. Eichinger WB, Hettich IM, Ruzicka DJ, et al. Twenty-year experience with the St. Jude medical Biocor bioprosthesis in the aortic position. Ann Thorac Surg 2008; 86: 1204-10.

\section{ENGLISH SUMMARY}

\section{Aortic valve replacement for aortic stenosis in Iceland 2002-2006: Indications and short term complications}

Ingvarsdóttir IL, Viktorsson SA, Hreinsson K, Sigurðsson MI, Helgadóttir S, Arnórsson P, Danielsen R, Guðbjartsson T

Objective: Information on surgical outcome of aortic valve replacement (AVR) has not been available in Iceland. We therefore studied the indications, short-term complications and operative mortality in Icelandic patients that underwent AVR with aortic stenosis.

Material and methods: This was a retrospective study including all patients that underwent AVR for aortic stenosis at Landspitali between 2002 and 2006, a total of 156 patients (average age 71.7 years, $64.7 \%$ males). Short term complications and operative mortality ( $\leq 30$ days) were registered and risk factors analysed with multivariate analysis.

Results: The most common symptoms before AVR were dyspnea (86.9\%) and angina pectoris (52.6\%). Preop. max aortic valve pressure gradient was on average $74 \mathrm{mmHg}$, the left ventricular ejection fraction $57.2 \%$ and EuroSCORE (st) $6.9 \%$. The average operating time was 282 min and concomitant CABG was performed in 55\% of the patients and mitral valve surgery in nine. A bioprothesis was implanted in 127 of the patients (81.4\%), of which 102 were stentless valves, and a mechanical valve in 29 (18.6\%) cases. The mean prosthesis size was $25.6 \mathrm{~mm}$ (range 21-29). Atrial fibrillation (78.0\%) and acute renal injury (36.0\%) were the most common complications and 20 patients (13.0\%) developed multiple-organ failure. Twenty-six patients (17.0\%) needed reoperation due to bleeding. Median hospital stay was 13 days and operative mortality was $6.4 \%$.

Conclusions: The rate of short term complications following AVR was relatively high, including reoperations for bleeding and atrial fibrillation. Operative mortality is twice that of CABG, which is in line with other studies. 